\title{
OCCUPATIONAL DISEASES IN POLAND - AN OVERVIEW OF CURRENT TRENDS
}

\author{
NEONILA SZESZENIA-DĄBROWSKA and URSZULA WILCZYŃSKA \\ Nofer Institute of Occupational Medicine, Łódź, Poland \\ Department of Occupational and Environmental Epidemiology, Central Register of Occupational Diseases
}

\begin{abstract}
Introduction: The number of occupational diseases (OD) recorded in Poland in the 1990's rapidly increased, and the number of recognized cases has steadily decreased until now. Hence, it was decided to demonstrate the trends of selected pathologies which in Poland are "underestimated" in comparison to other countries. The presented data may constitute a basis for further research into the dependence of OD on socio-economic factors. Materials and Methods: Occupational Disease Reporting Forms, completed and sent obligatorily by the state health inspectors to the Central Register of Occupational Diseases were used as source documents for analysis. This work analyzes changes in the incidence of chronic poisonings, asbestosis, voice organ diseases, cancers, viral hepatitis, asthma and the musculoskeletal disorders over the years 1998-2011. Results: In 1998, the total number of registered diseases reached the maximum - 12,017 cases, which fell in the subsequent years to 2,562 cases in 2011. During that period, the incidence rate decreased by 6 cases per year per 100,000 employees. A considerable decrease, exceeding $90 \%$ of cases, was observed in voice organ disorders, hearing loss, chronic poisonings and viral hepatitis. The abovementioned changes, as well as improved detection of asbestos-related diseases through implementing a medical examination program of former asbestos processing plant workers, are advantages of the current situation in the epidemiology of OD. However, the disadvantages include underestimation, in comparison to other countries, of asthma, cancer and pathologies of the musculoskeletal system. Conclusion: The reported data indicates the need to assess the occupational fraction of the underestimated pathologies present in the work environment in Poland, as well as the need for studies aimed at clarifying the effect of systemic factors on identifying their occupational background.
\end{abstract}

Key words:

Occupational poisoning, Asbestosis, Cancer, Viral hepatitis, Asthma

\section{INTRODUCTION}

Occupational disease is a medical/legal concept. It entails medical diagnosis and, as its integral part, assessment of exposure and working conditions, as well as the administrative decision confirming that the applicant has developed the disease as a result of that exposure, which may serve as the basis to apply for financial compensation for the suffered health loss.

The incidence of occupational pathologies and their clinical forms remains in close association with the development of industry, introduction of new substances and theoretical knowledge concerning their effects on the human body, conditions and organization of work, economic development, labor protection and social security system for those affected. The state is responsible for legal system ensuring the protection of the life and health of employees, while it is the employer who is responsible for ensuring safe working conditions that meet determined standards.

In Poland, the currently valid list of occupational diseases, which at present contains 26 items with a total of 59

This work was performed as part of the project "Monitoring of the cases of occupational diseases in Poland" (IMP 10.4/2012). Project manager: Prof. Neonila SzeszeniaDąbrowska.

Received: September 9, 2012. Accepted: April 25, 2013.

Corresponding author: N. Szeszenia-Dąbrowska, Department of Occupational and Environmental Epidemiology, Central Register of Occupational Diseases, Nofer Institute of Occupational Medicine, św. Teresy 8, 91-348 Łódź, Poland (e-mail: wies@imp.lodz.pl). 
sub-items is in compliance with the European Schedule of Occupational Diseases [1]. Since 1974, the Polish list has included "diseases of the organ of voice".

Institutions authorized to recognize occupational diseases include specialist health care units (outpatient clinics, hospital wards) employing occupational medicine experts. People with suspected occupational disease are referred to those units. Administrative decisions about occupational diseases are issued by state sanitary inspectors, who are obliged to report each recognized case of occupational disease to the Central Register of Occupational Diseases by means of a duly completed Occupational Disease Reporting Form. The decision certifying that the diagnosed health condition is an occupational disease is a document that allows the patient to apply for financial compensation.

\section{MATERIALS AND METHODS}

Cases of occupational diseases reported obligatorily over the years 1998-2011 to the Central Register of
Occupational Diseases, run by the Nofer Institute of Occupational Medicine in Łódź, were used as a material for analysis. The number of cases of selected occupational disease incidence in terms of the coefficient per 100,000 employees, and the linear trend (according to the method of least squares) of those parameters in 1998-2011 were analyzed. Also, the mean period of exposure preceding the development of the disease has been specified.

The number of occupational diseases recognized in the period 1998-2011 amounted to 70,265 cases, of which most numerous were chronic voice disorders (26.7\%), hearing loss $(17.7 \%)$, pneumoconioses $(15.1 \%)$, infectious and parasitic diseases (14.9\%) followed by skin diseases $(5.6 \%)$, asthma (3.1\%), vibration syndrome (3.0\%), chronic diseases of the peripheral nervous system $(2.7 \%)$, chronic diseases of the locomotor system $(2.6 \%)$, malignant neoplasms (2.2\%), allergic rhinitis $(2.1 \%)$, acute and chronic intoxications $(2.0 \%)$ as well as chronic obstructive bronchitis $(1.1 \%)$. Each other pathology represented less than $1 \%$ of the total number of occupational diseases.

Table 1. Occupational diseases in Poland in selected years

\begin{tabular}{|c|c|c|c|c|c|c|c|c|c|c|c|c|}
\hline \multirow[t]{2}{*}{ Occupational diseases } & \multicolumn{6}{|c|}{$\begin{array}{l}\text { Cases in particular year } \\
\text { (n) }\end{array}$} & \multicolumn{6}{|c|}{$\begin{array}{l}\text { Cases per } 100000 \text { paid employees in particular year } \\
\text { (n) }\end{array}$} \\
\hline & 1998 & 2001 & 2008 & 2009 & 2010 & 2011 & 1998 & 2001 & 2008 & 2009 & 2010 & 2011 \\
\hline Total & 12017 & 6007 & 3546 & 3146 & 2933 & 2562 & 117.3 & 63.2 & 34.7 & 29.9 & 28.3 & 24.6 \\
\hline Poisonings & 294 & 136 & 26 & 14 & 14 & 14 & 2.9 & 1.4 & 0.3 & 0.1 & 0.1 & 0.1 \\
\hline Asbestosis & 86 & 173 & 112 & 92 & 88 & 63 & 0.8 & 1.8 & 1.1 & 0.9 & 0.8 & 0.6 \\
\hline Chronic voice disorders & 3654 & 1680 & 809 & 623 & 321 & 228 & 35.7 & 17.7 & 7.9 & 5.9 & 3.1 & 2.2 \\
\hline Viral hepatitis type B & 769 & 304 & 30 & 31 & 24 & 18 & 7.5 & 3.2 & 0.3 & 0.3 & 0.2 & 0.2 \\
\hline Viral hepatitis type $C$ & & & 119 & 99 & 72 & 49 & & & 1.2 & 0.9 & 0.7 & 0.5 \\
\hline Bronchial asthma & 275 & 211 & 89 & 52 & 44 & 47 & 2.7 & 2.2 & 0.9 & 0.5 & 0.4 & 0.5 \\
\hline Malignant tumors & 137 & 128 & 100 & 95 & 100 & 96 & 1.3 & 1.3 & 1.0 & 0.9 & 1.0 & 0.9 \\
\hline lung cancer & 65 & 72 & 57 & 56 & 50 & 64 & 0.6 & 0.8 & 0.6 & 0.5 & 0.5 & 0.6 \\
\hline $\begin{array}{l}\text { pleural or peritoneal } \\
\text { mesothelioma }\end{array}$ & 6 & 18 & 14 & 17 & 32 & 17 & 0.1 & 0.2 & 0.1 & 0.2 & 0.3 & 0.2 \\
\hline Musculoskeletal diseases & 284 & 124 & 120 & 110 & 131 & 101 & 2.8 & 1.3 & 1.2 & 1.0 & 1.3 & 1.0 \\
\hline Carpal tunnel syndrome & 149 & 92 & 142 & 151 & 187 & 181 & 1.5 & 1.0 & 1.4 & 1.4 & 1.8 & 1.7 \\
\hline
\end{tabular}


The analysis included the following categories: chronic poisonings (1372 cases), asbestosis (1494), voice organ diseases (18,764), viral hepatitis (3350), bronchial asthma (1996), cancers (1555), musculoskeletal diseases (1862) and carpal tunnel syndrome (1759) (Table 1). Those pathologies represented $45.9 \%$ of the total number of cases. For asbestosis, chest X-ray images of 3423 former workers of asbestos processing plants, taken over the years 2001-2010 under the "Amiantus" project, were also included in the analysis as source data [2].

\section{RESULTS AND DISCUSSION}

A significant decrease in the absolute number of occupational diseases has been noted in Poland since 1998, as has a continuing reduction in the incidence rate following a sharp rise observed in the period 1991-1998. This has justified undertaking an epidemiological analysis, especially in the context of frequently-repeated erroneous opinions that the reduction was attributable to the improvement of working conditions (Figure 1).
Various pathologies must be considered separately because, depending on the type of pathology, different factors can decrease, or increase, their occurrence to varying degrees.

However, it should be borne in mind that occupational pathologies are generally the result of long-term occupational exposure to harmful or annoying factors, for about 15-25 years, and become apparent not only during the employees' working lives but also at the retirement age (Table 2). The significant increase and decrease in the frequency of occupational diseases in Poland during the studied period was the result of a combination of various causative factors, generally speaking, associated with the process of the national economy transformation.

Starting the process of economic transformation in the 90's led initially to the dissolution and liquidation of large state-owned factories using old technologies that posed significant risk to the health of employees. In 1998, 51 large enterprises (mines, steel mills, automotive plants, metallurgical plants) recorded over 15 occupational diseases. Those enterprises were responsible for about $26 \%$

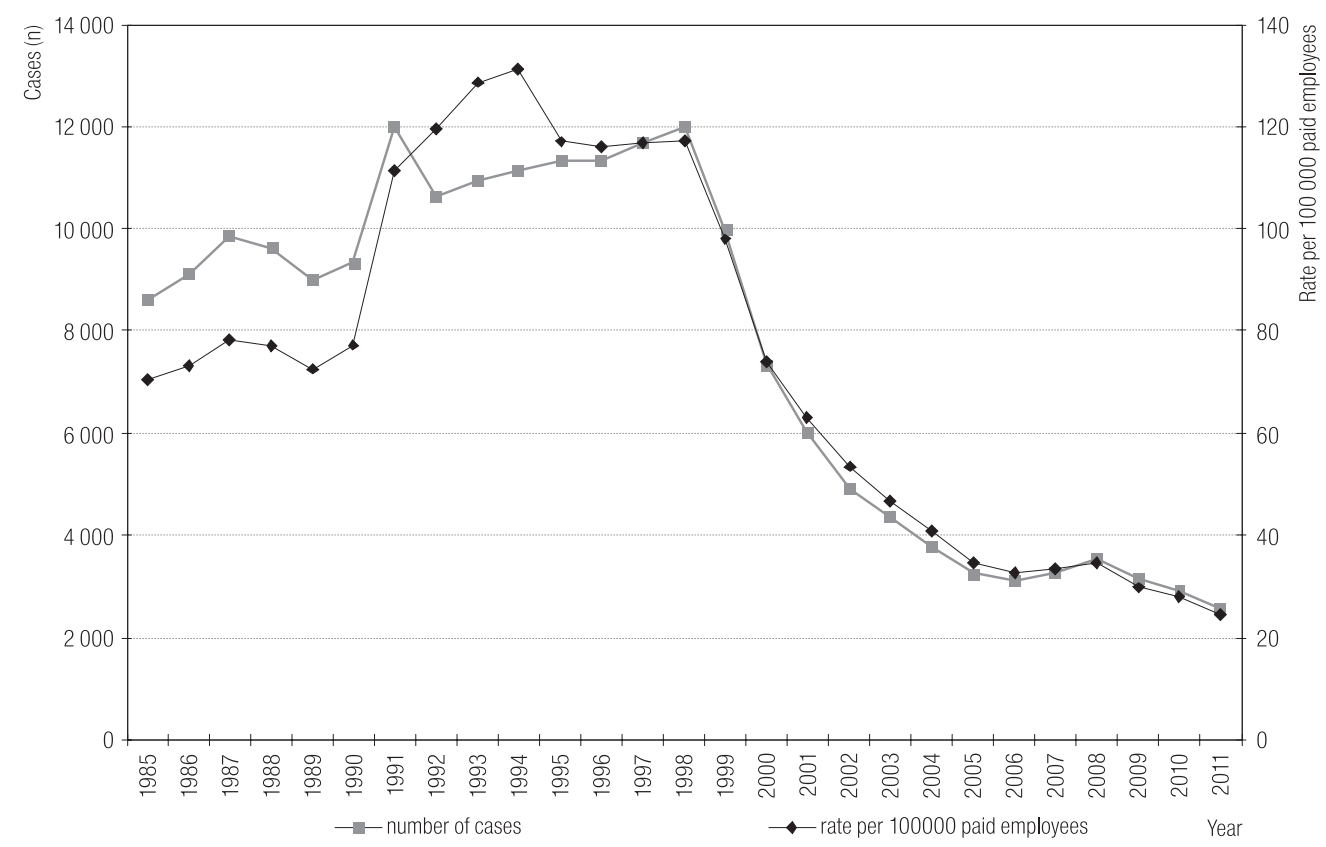

Fig. 1. Occupational diseases in Poland in 1985-2011 
Table 2. Duration of exposure and percentage of cases recognized in patients at pensionable age for selected occupational diseases, 2008-2011

\begin{tabular}{lccc}
\hline \multicolumn{1}{c}{ Occupational diseases } & $\begin{array}{c}\text { Cases } \\
(\mathrm{n})\end{array}$ & $\begin{array}{c}\text { Duration of exposure } \\
\text { (years) } \\
\mathrm{M} \pm \mathrm{SD}\end{array}$ & $\begin{array}{c}\text { Cases recognized } \\
\text { at pensionable age* } \\
(\%)\end{array}$ \\
\hline Asbestosis & 355 & $14.7 \pm 8.7$ & 59.2 \\
Chronic voice disorders & 1981 & $25.5 \pm 1.6$ & 20.0 \\
Malignant tumors & 391 & $18.7 \pm 8.8$ & 38.1 \\
$\quad$ lung cancer & 227 & $19.0 \pm 8.4$ & 34.8 \\
$\quad$ pleural or peritoneal mesothelioma & 80 & $16.2 \pm 9.6$ & 43.7 \\
Musculoskeletal diseases & 462 & $20.6 \pm 8.0$ & 7.4 \\
Carpal tunnel syndrome & 661 & $21.6 \pm 7.1$ & 4.3 \\
\hline
\end{tabular}

$\mathrm{M}$ - mean; SD - standard deviation.

* 65 years in men, $\geq 60$ years in women.

of all occupational diseases, including $66 \%$ of pneumoconioses and 50\% of hearing loss cases. In 2011, the number of companies with at least 15 cases of recognized occupational diseases fell to 10 .

The process of economic transformation was associated with elimination of outdated technologies, introduction of automation and encapsulation of production, leading to a significant reduction in the concentration and intensity of harmful agents in the workplaces. During the first stage, the transformation process posed the risk of job loss for a great number of employees, and resulted in unemployment rates of up to $20 \%$ of the working age population. The risk of job loss resulted in enormous pressure exerted by workers in various sectors of the economy wishing to obtain benefits associated with work-related loss of health. The rapid increase in the total number of occupational diseases over the years 1991-1998 was related to all groups of occupational diseases found on the current list. In 1998, the total number of recognized diseases was 12,017 cases, while in 2011, it fell to 2562 cases, i.e. was by $78.7 \%$ lower. During that period, the number of cases per 100,000 employees decreased by $6 /$ year $(y=-6.0 x+95.6)$. Major decreases in the number of cases were recorded for the diseases which previously showed the largest growth, i.e. diseases of the voice organs, a decrease of 3426 cases ( $36.2 \%$ of total decrease), and hearing loss, a decrease of 3127 cases (33.1\% of total decrease). A considerable per cent decreases were observed in chronic poisonings $(95.2 \%)$, bronchial asthma (87.6\%) and musculoskeletal disorders (64.4\%), i.e. diseases with a relatively low starting level of incidence in 1998 (Table 1).

\section{Poisonings}

The most evident example of the changes occurring in the profile of recognized occupational diseases are chronic poisonings with chemicals, which in the 1960s, accounted for about $1 / 3$ of all cases of occupational diseases, and were mainly caused by lead, carbon monoxide and benzene. In 2011, there were 14 cases of such poisonings, i.e. $0.5 \%$ of all the recognized occupational diseases (Table 3 ).

In the period 1998-2011, the number of poisoning cases decreased at an average rate of 19 cases per year (Figure 2). The decrease was statistically significant $(\mathrm{t}=7.882$, $\mathrm{p}<0.001)$. Remote effects of poisoning with carbon disulfide (CS2) constituted the most common pathology in this category. The relatively large impact of this factor, no doubt influenced by the socio-economic situation, was associated 
Table 3. Occupational poisonings in selected years

\begin{tabular}{lrrrrrrrrrr}
\hline \multirow{2}{*}{ Occupational diseases } & \multicolumn{3}{c}{1967} & \multicolumn{2}{c}{1998} & \multicolumn{2}{c}{2008} & \multicolumn{2}{c}{2010} & \multicolumn{2}{c}{2011} \\
\cline { 2 - 11 } & $\mathrm{n}$ & \multicolumn{1}{c}{$\%$} & $\mathrm{n}$ & $\%$ & $\mathrm{n}$ & $\%$ & $\mathrm{n}$ & $\%$ & $\mathrm{n}$ & $\%$ \\
\hline Total & 4485 & 100.0 & 12017 & 100.0 & 3546 & 100.0 & 2933 & 100.0 & 2562 & 100.0 \\
Chemical poisonings & 1400 & 31.2 & 294 & 2.4 & 26 & 0.7 & 14 & 0.5 & 14 & 0.5 \\
Caused by: & & & & & & & & & & \\
$\quad$ lead & 526 & 11.8 & 38 & 0.3 & 1 & 0.0 & 5 & 0.2 & 1 & 0.0 \\
carbon monoxide & 236 & 5.3 & 32 & 0.3 & 2 & 0.1 & - & - & 5 & 0.2 \\
benzene & 207 & 4.6 & 5 & 0.0 & 1 & 0.0 & 1 & 0.0 & - & - \\
carbon disulfide & 127 & 2.8 & 130 & 1.1 & 11 & 0.3 & 3 & 0.1 & 2 & 0.1 \\
$\quad$ other substance & 304 & 6.7 & 89 & 0.7 & 11 & 0.3 & 5 & 0.2 & 6 & 0.2 \\
\hline
\end{tabular}

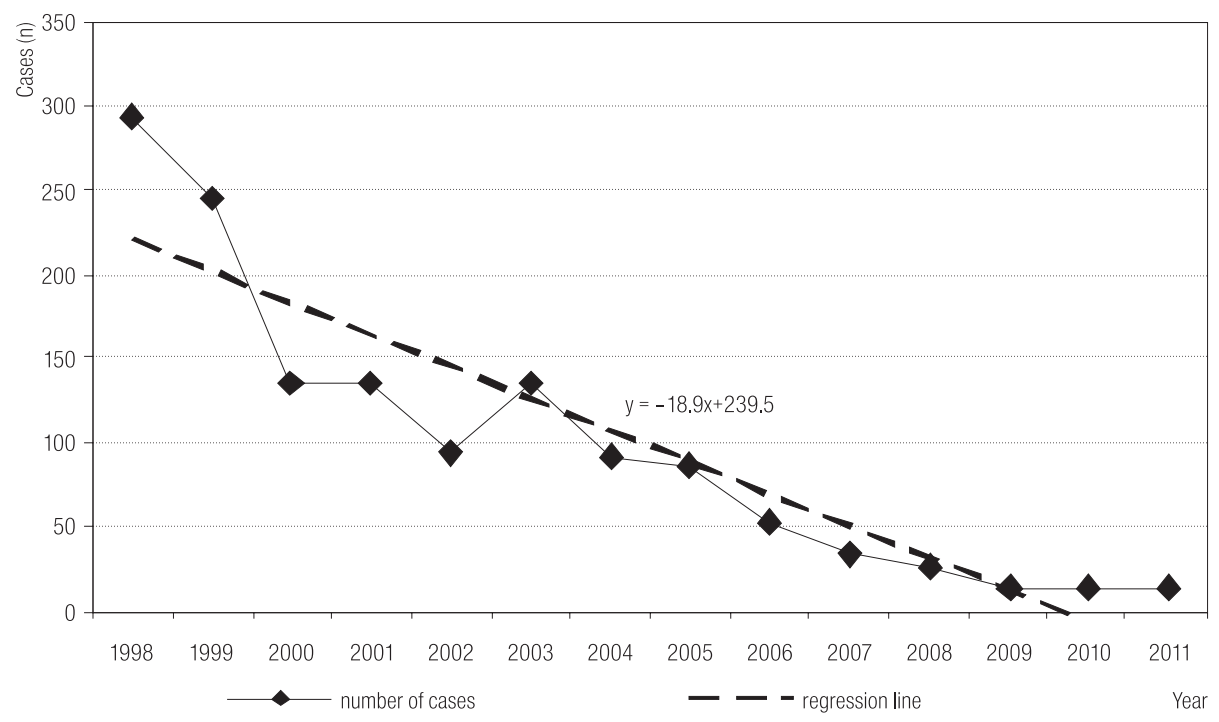

Fig. 2. Occupational poisonings in 1998-2011

with the closure during the 1990's of the artificial (viscose) fibre plants characterized by exposure to CS2.

The small number of currently recorded poisonings is an advantageous aspect of the changes in the epidemiology of occupational diseases. However, it may be a result of under-registration of the actual number.

\section{Asbestosis}

The incidence of asbestosis is a good example of the influence of medical factors on the current epidemiological situation. Implementation of prophylactic examination programs in selected groups of exposed workers usually increases the detected pathology at the outset. This was demonstrated by a sharp increase in the number of cases of asbestosis over the years 1981-1983, when preventive examinations were performed in employees of several large asbestos-processing plants. This effect was also observed after the implementation of the program of medical examinations in former asbestos workers in 2001. Even though the manufacture of asbestos products was stopped in 1998, the latency period is very long and overt symptoms of asbestos-related diseases may appear a long 


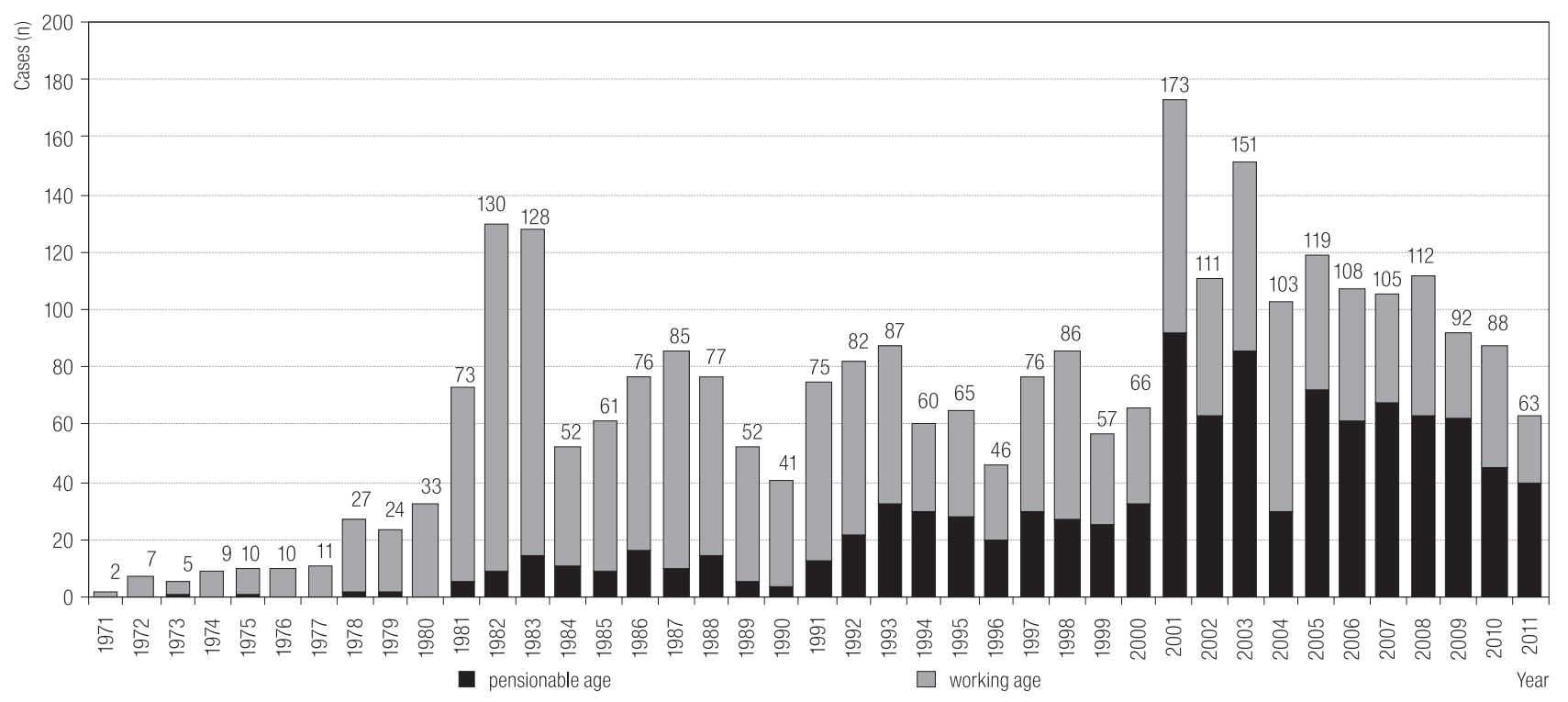

Fig. 3. Asbestosis over the years 1971-2011, including the cases recognized in pensionable age

time after exposure termination. The average latency period of asbestosis diagnosed in 2008-2011 was 39 years $(\overline{\mathrm{x}} \pm \mathrm{s}=39.2 \pm 9.6)$, which is why overt symptoms of this disease appear in a high percentage of people at pensionable age (Figure 3) Table 2.

Chest radiography and detection of the changes in the $\mathrm{X}$-ray chest image are crucial in the recognition of asbestosis. The diagnosis of asbestosis relies on detecting the presence of X-ray changes such as small irregular s, t, u type opacities with densities starting from $1 / 0$, which is in accordance with the ILO radiological classification of dust diseases [3,4]. In Poland, asbestosis as an occupational disease is recognized in the case of radiographic changes starting from the 1/1 category of density [5].

Periodic chest radiography examinations in former workers of asbestos processing plants (the Amiantus Project), were performed over the years 2001-2010. The results showed that adoption of the international criteria for the density of opacities (from 1/0) would result in an increase of the number of people with recognized asbestosis by a total of $13 \%$, depending on the sector - from $8 \%$ in the workers exposed during the production of roofing products, asphalt and filter masses up to $26 \%$ in those exposed during the production of sealing (Table 4).

Table 4. Chest radiograph examinations in the former workers of asbestos plants classified by the ILO system, 2001-2010

\begin{tabular}{lccccc}
\hline \multirow{2}{*}{$\begin{array}{c}\text { Asbestos processing plants } \\
\text { by type of product }\end{array}$} & \multicolumn{3}{c}{ Density of small irregular opacities of s, t, u type } & \multirow{2}{*}{$\begin{array}{c}\text { Chest } \\
\text { radiographs }\end{array}$} \\
\cline { 2 - 5 } & $0 / 0$ & $0 / 1$ & $1 / 0$ & $1 / 1-2 / 3$ & $(\mathrm{n})$ \\
\hline Asbestos-cement & 37.5 & 28.5 & 12.8 & 21.2 & 1881 \\
Textile & 32.4 & 21.8 & 14.1 & 31.7 & 262 \\
Packings and seals & 31.4 & 32.5 & 26.0 & 10.1 & 277 \\
Frictional & 57.2 & 27.3 & 11.9 & 3.6 & 477 \\
Hydroinsulating & 70.5 & 14.8 & 8.2 & 6.5 & 526 \\
Total & 44.5 & 26.0 & 13.1 & 16.4 & 3423 \\
\hline
\end{tabular}




\section{Chronic voice organ disorders}

A rather more complicated situation is observed in the case of the incidence of diseases of the voice organ, defined as chronic diseases and caused by excessive vocal effort continuing for at least 15 years. In 1998, they accounted for $30.4 \%$ of all cases of occupational diseases. This pathology mainly affects teachers (over $95 \%$ of cases). The increase in the voice organ diseases in the late 1990's was due to socio-economic factors associated with education system reform and the fear of unemployment, especially among teachers with tenures longer than 20 years. These social facts were underpinned by the lack of objective methods of diagnosing diseases of the larynx caused by vocal effort [6].

A considerable reduction in the frequency of the occupational pathologies of the voice organ, which in 2011 already accounted for $8.9 \%$ of all occupational diseases, resulted mainly from the resignation in previous years by a large number of teachers with long years of service. A reliable diagnosis became possible due to the appearance of clinics with modern equipment enabling objective assessment of the pathology (videolaryngostroboscopy) and due to explaining the nature of lesions caused by excessive vocal effort [7]. As a result, a decline in the annual incidence rate of chronic voice disorders by an average of 24 cases per 100,000 teachers was reported in 1998-2011 (Figure 4). The decrease was statistically significant $(\mathrm{t}=6.443, \mathrm{p}<0.001)$.

Implementation of the voice organ disease prevention programs among teachers and students trained for teaching jobs, as well as improvement of the diagnostic procedures will undoubtedly contribute to reducing the incidence, but more than 10 years are needed to fully evaluate the effects of these actions.

\section{Viral Hepatitis}

Viral hepatitis is now the most frequently diagnosed infectious disease, after borreliosis, which over the years 1998 2011 accounted for $32.4 \%$ of all cases of occupational diseases in the group of infectious and parasitic diseases and their sequels. Hepatitis mainly affects medical and auxiliary personnel working in health care facilities (94.2\% of diagnosed cases), and is the most common occupational disease among that professional group [8]. Introduction

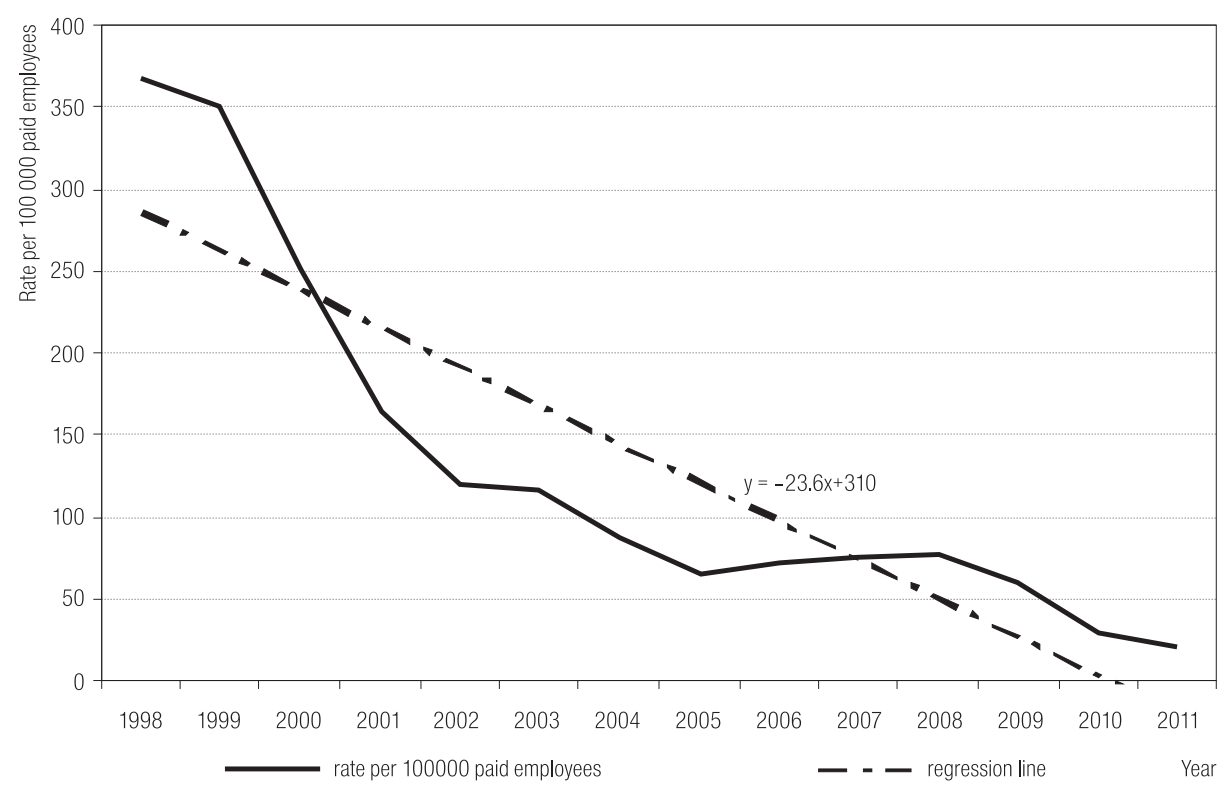

Fig. 4. Incidence of chronic voice disorders among education workers over the years 1998-2011 


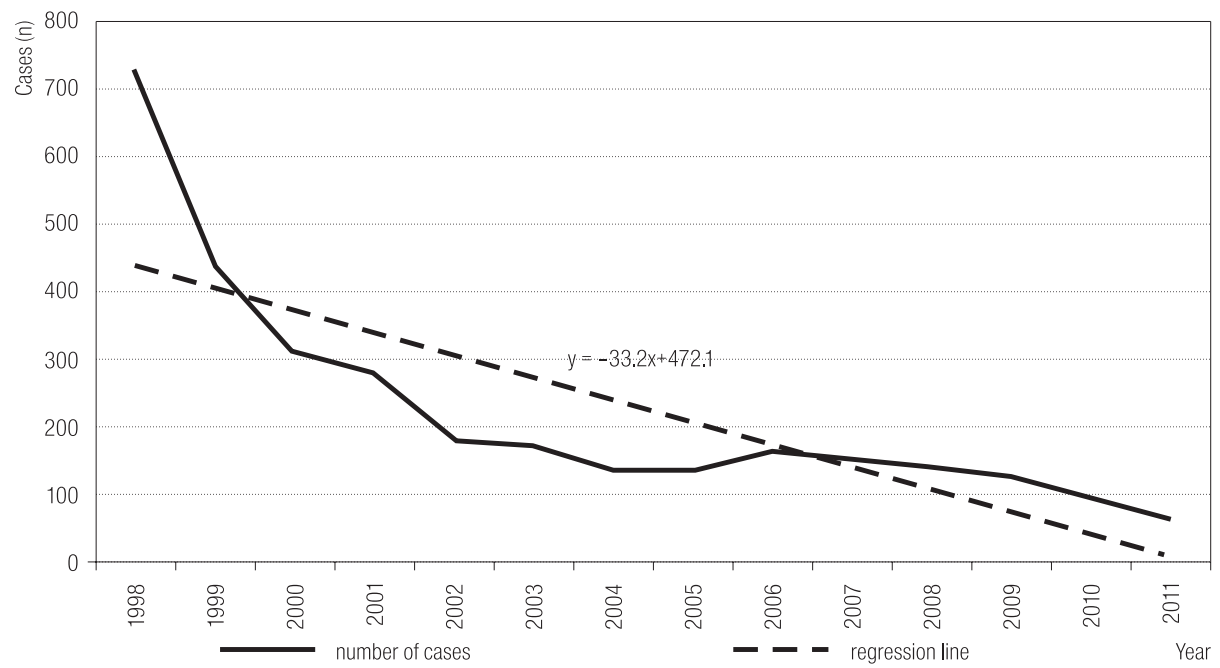

Fig. 5. Viral hepatitis among health and social workers over the years 1998-2011

of vaccination against hepatitis B among health personnel in 1988 resulted in an evident decrease in the incidence. In 2011, the number of cases decreased by $91 \%$ compared to 1998 values, and the average annual number fell by about 33 , which constitutes a significant value $(\mathrm{t}=4.661$, $\mathrm{p}<0.001$ ) (Figure 5).

The decreasing number of cases of the disease is dominated by the hepatitis $\mathrm{C}$ virus, which in the last five years has accounted for more than $75 \%$ of all hepatitis cases. As regards viral hepatitis diagnosis in Poland, the problem is that the tests for anti-hepatitis $\mathrm{C}$ virus (HCV) and anti-hepatitis B surface antigen (HBsAg) antibodies, as well as assessment of the effectiveness of HBV vaccination among medical staff before and during employment are not obligatory [9].

\section{Asthma}

Bronchial asthma is the most common occupational respiratory disease in economically developed countries. The general assumption is that the actual number of cases of occupational asthma is significantly underestimated. In the UK, it is assumed that the true value is underestimated by one third of new cases [10]. The occupational fraction of the overall incidence of asthma among adults is estimated at $10-15 \%$ [11-13], while in developed and rapidly-developing countries, those fractions are estimated at $13-14 \%$, and in poor countries, the corresponding value is $6 \%$ [14]. In Sweden, the fraction of occupational asthma is estimated among men at $29 \%$, and among women at $17 \%$ [15].

In 12 European Union countries, in 2001, cases of asthma accounted for $23.8 \%$ of all occupational lung diseases [16]. In Belgium, in 1993-2002, the incidence of occupational asthma per year averaged 2.9/100,000 with a downward trend of about 3.6 in 1993 to 2.6 in 2002. The reduction in the registered cases is a trend recently observed on a global scale [17,18]. In Scandinavia, the annual incidence remained at a high level of about 18 cases per 100,000 employees, while in the underdeveloped countries the incidence amounts to 2 cases per 100,000 employees [13,19]. Bronchial asthma in Poland in 2011, with a rate of $0.5 / 100000$ workers accounted for $7.4 \%$ of all occupational respiratory diseases. Despite the relatively low incidence, the number of recognized cases has been significantly declining by approximately 20 cases per year $(\mathrm{t}=10.98, \mathrm{p}<0.001)$ (Figure 6).

Flour dust is quoted as the most frequent $(52.1 \%)$ cause of asthma. The incidence of occupational asthma is 


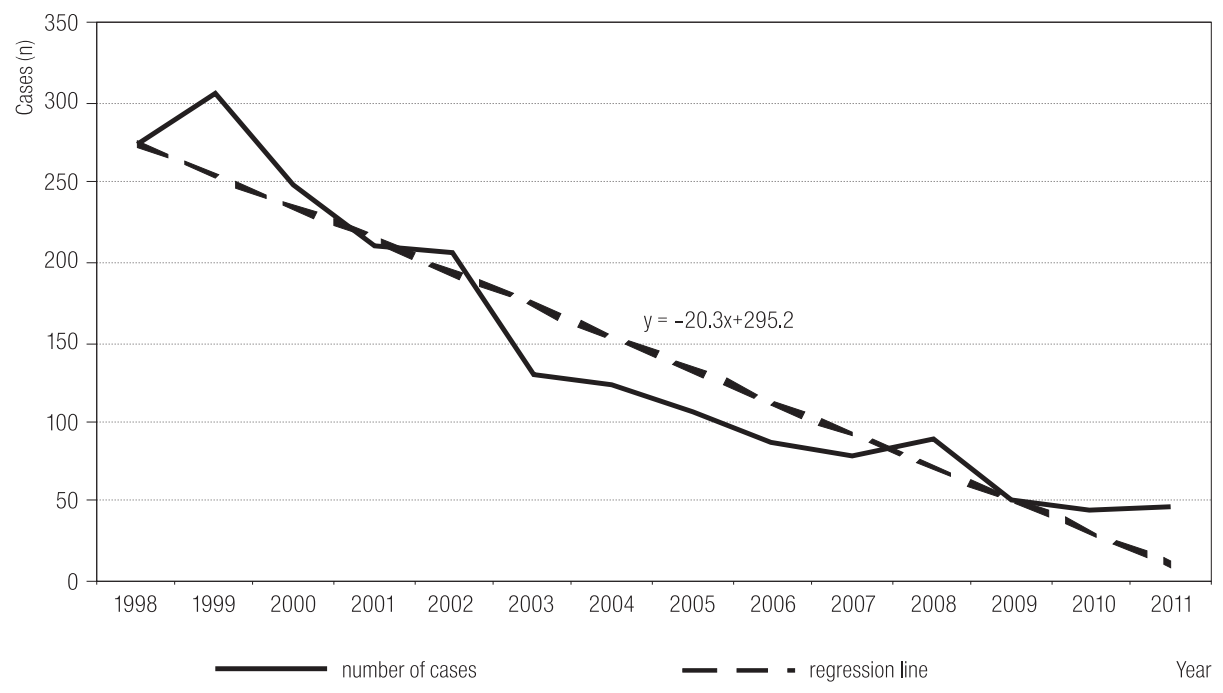

Fig. 6. Number of cases of bronchial asthma over the years 1998-2011

clearly related to occupations and industries in which the risk of developing that disease is high. In Poland, every second person with a certified occupational asthma has been employed in the production, storage or sale of food under conditions of exposure to flour dust [20]. The large variation in the incidence of asthma between countries results from the lack of strategies for identifying potential allergenic factors and cases of the disease in the work environment, and the lack of standardized diagnostic methods and surveillance systems $[12,21]$ which in Poland, according to the presented data, require urgent improvement.

\section{Occupational cancers}

The general assumption is that the number of occupational tumors has been considerably underestimated. In general, contribution of occupational cancers to the total incidence and rate of deaths due to cancer varies depending on the current and former use of carcinogens in the economy of the country, the level of exposure, exposed population and duration of exposure, as well as the period of time for which the assessment was continued. Contribution of occupational factors to deaths due to cancer has been estimated as $4 \%$ of the the total U.S. population (15\% of the male population) [22] and at $5.3 \%$ of the the total U.K. population $(8.2 \%$ of the male population) [23]. In France and Scandinavian countries, these estimates for men are slightly lower, i.e. $2.7 \%$ [24] and 3\% [25] respectively. The occupational fraction of lung cancer in men is estimated at $2 \%$ to $15 \%$ and even up to $40 \%$ [11,22,26,27].

The presented estimates differ significantly from the reported number of cases recognized as an occupational disease. From 87 to 142 cases of occupational cancer per annum were recognized during the period 1998-2011 in Poland. Contribution of cancers recognized as an occupational disease to the total number of new cancer cases in the general population in that period was about $0.1 \%$, and the corresponding number for lung cancer was $0.4 \%$. Lung cancer in that period accounted for more than $56 \%$ of all occupational cancer cases. A similar situation was observed in analyses of occupational lung cancer incidence in the countries of Central Europe: the Czech Republic, Slovakia and Hungary [28], Germany [29] and Italy [30]. In Poland, occupational lung cancer cases, which are considerably underestimated, in recent years have remained at the level of fifty-odd cases a year, showing a slightly downward trend (Figure 7). The major 


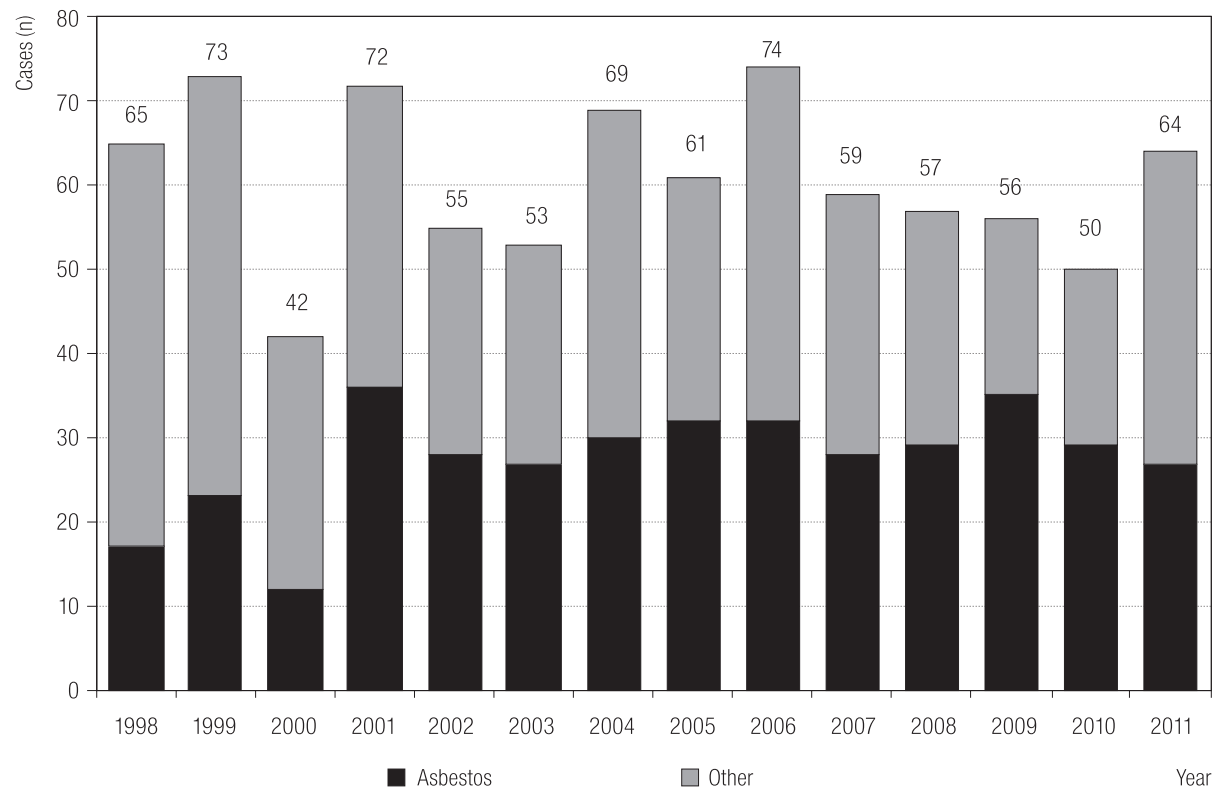

Fig. 7. Occupational lung cancer, including cases due to asbestos over the years 1998-2011

causal factor for occupational lung cancer was asbestos (approximately in 50\% of cases). Contrary to these figures, according to the statistics of the European Union countries, in 2001, lung cancer accounted for only $14 \%$ of all reported occupational cancer cases, while mesothelioma accounted for as much as $78 \%$ of those cases [16]. Mesothelioma is a typical example of underestimation of occupational tumors; $85-97 \%$ of the etiologic fraction is attributable to asbestos [27]. Over the years 2006-2008, the mean annual number of mesothelioma cases in the general population in Poland was 199, including $11.6 \%$ of cases recognized as occupational diseases. In Scandinavian countries, although $42-57 \%$ of the total number of mesotheliomas occurring in the general population recognized as occupational diseases, this proportion is now thought to represent a significant underestimation of the occupational etiology of this tumor [31,32]. Over the years 1998-2011, the contribution of mesotheliomas to the total incidence of occupational tumors in Poland amounted to $15.4 \%$.

Recognition of the occupational origin of cancer is a source of major difficulties and controversy in occupational medicine practice which results, among other things, from the non-specificity of occupational cancers and the resultant need to use the concept of risk in relation to occupational carcinogens. The quantified risk reflecting the possibility of development of cancer in people exposed to a specific carcinogen is much less useful in taking decisions in individual cases.

The reasons for the underestimation of occupational cancers include, among others, the relatively small number of identified carcinogens in the workplace, long latency period, and hence, in many cases, appearance of symptoms after termination of occupational exposure. A considerable percentage of occupational tumors appear at retirement age, while the lack of interest and insufficient knowledge on occupational carcinogens among physicians result in those cancers being underestimated in this age group. In Poland, in 2008-2011, about 41\% (women: $59 \%$, men: $38 \%$ ) of the total number of occupational cancers were recorded at pensionable age (Table 2). The failure to apply for recognition of the occupational origin of tumor by the affected individuals and their families, estimated to constitute $95 \%$ of the total number of 
cancer cases attributable to occupational exposure, has resulted in occupational cancer being regarded as a marginal problem in occupational medicine, which in turn results in neglecting its prophylaxis [33]. In the prevention strategy, determination of the fraction assigned to occupational factors responsible for the development of various cancers, identification of new carcinogens and their target organs, surveillance of workers exposed to carcinogens and elucidation of interaction between occupational carcinogens and lifestyle factors are of vital importance [34,35].

\section{Musculoskeletal disorders}

Occupational diseases of the musculoskeletal system and symptoms caused by impaired function of the peripheral nervous system constitute a serious clinical and social problem, which is a major cause of temporary and permanent inability to work in many sectors and occupations. The observed growth of those pathologies, especially in the developed countries, is associated with the implementation of new work technologies [36-38].

In the EU, diseases of the musculoskeletal system were the most commonly reported work-related issues in 2001, representing $35 \%$ of all reported occupational diseases. Carpal tunnel syndrome, belonging to the diseases of the peripheral nervous system, took the 6th place. Both these pathologies, together, accounted for almost $43 \%$ of all reported occupational diseases [16]. In Poland, in the same year, cases of occupational diseases of the musculoskeletal system and carpal tunnel syndrome accounted only for $3.6 \%$ of total occupational diseases.

Over the years 1998-2011, 1759 cases of carpal tunnel syndrome and 1832 cases of diseases of the musculoskeletal system were reported in Poland; together, they accounted for $5.1 \%$ of all occupational diseases. Both these pathologies are observed primarily in women $(79.6 \%$ and $56.5 \%$, respectively). After a decline in the number of cases in the first half of the period, a slight upward trend is now emerging (Figure 8).

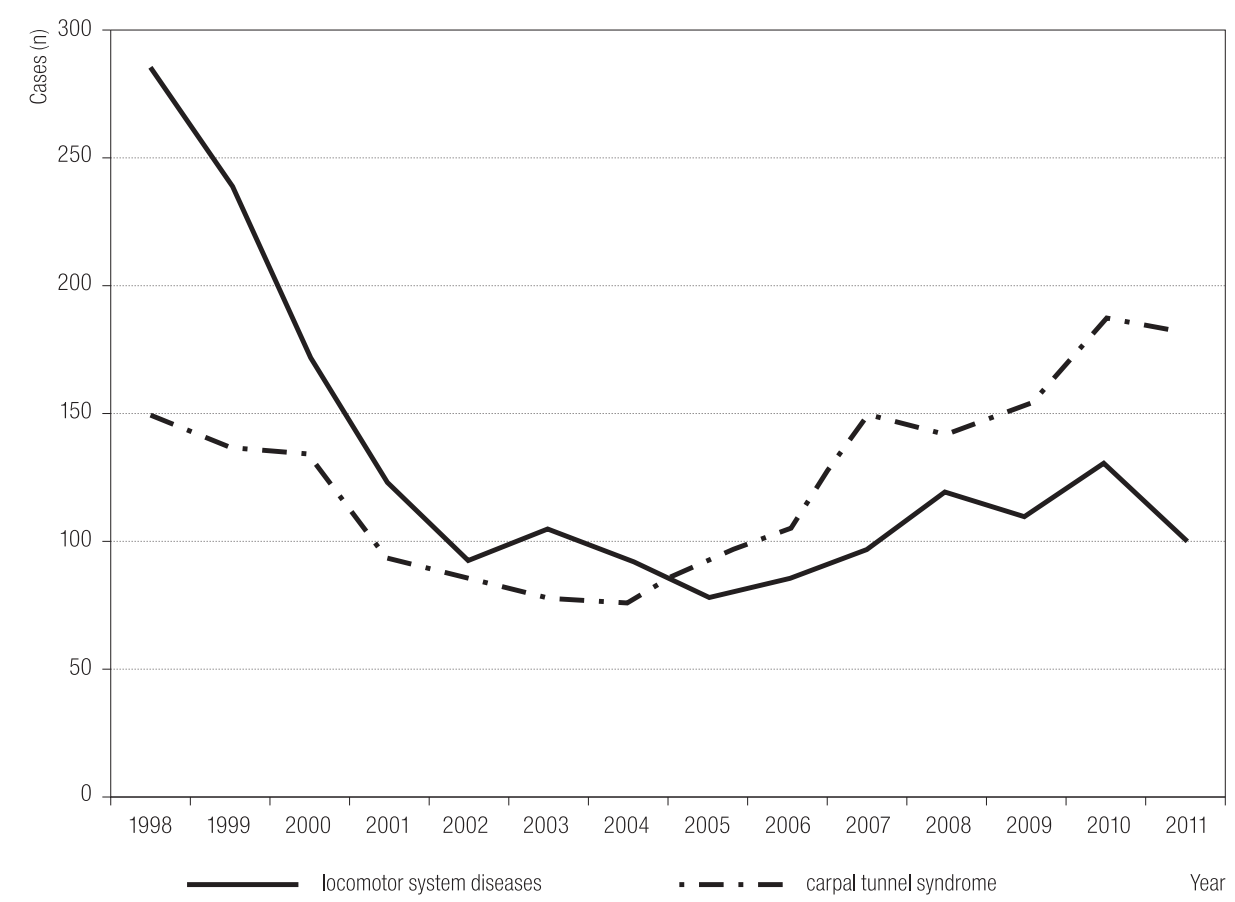

Fig. 8. Musculoskeletal diseases and carpal tunnel syndrome over the years 1998-2011 


\section{Concluding remarks}

A statistical analysis of the reported cases over longer periods of time reveals both upward and downward trends in the incidence of various types of diseases and changes in their distribution. The changes presented in this work should be regarded with caution due to the specific character of the term "occupational disease", which combines medical and legal aspects. Thus, the incidence of occupational diseases is affected by factors related to the medical component, as well as socio-economic factors and governmental policy on social benefits [39].

The national economy transformation that has continued since 1989 has resulted in the closure of many large state-owned industrial enterprises. The employment profile has changed, there has been a considerable reduction in the share of the public sector, now employing only every fourth person of the total Polish workforce (in 1989, the public sector employed as much as $96 \%$ of the workforce). The services and trade sector has expanded and the number of self-employed persons has increased. The shift of labor to the sphere of services and highly skilled office work will cause changes in the profile of occupational pathologies because it will bring about a change in the character and intensity of harmful factors and workload levels. Owing to the mechanization and automation of many processes, the dynamic effort of workers is being replaced by static load. These changes have increased the share of women in the identified cases of occupational diseases that occur in economic sectors employing large proportions of women (education $-77.4 \%$ of women, health care $-82.7 \%$, trade $-56.5 \%$, services $-64.4 \%$ [40]). The changing pattern of occupational hazards has not yet been reflected in the content of the current list of occupational diseases.

Medical factors affecting the frequency of recognized medical pathologies include medical care, diagnostic facilities, launching large-scale medical examinations and implementation of prevention programs. The lack of a clear, universally acceptable methodology for assessment of the contribution of occupational factors to the development of symptoms and diseases of multifactorial etiology occurring to a significant degree in the general population (e.g. stress and its health consequences, cardiovascular diseases, neuroses, diseases of the musculoskeletal system) continues to be an obstacle to extending the list of occupational diseases so that it would include effects of working in contemporary conditions. Changing the approach to the recognition of occupational disease brings about specific legal and economic consequences.

The transformation of the national economy in Poland was accompanied by changes in the organization of healthcare for the working population. When large industrial facilities dominated Poland's economic scene, medical care was strictly institutionalized, while currently it is liberalized and dispersed. At present, numerous smaller companies and sometimes self-employed workers are no longer subject to such strict supervision for labor safety and health. It seems quite likely that employees and/or employers fail to report their workrelated health problems to the occupational healthcare system. Such a situation may lead to an increase in the incidence of occupational diseases in the future.

The observed favorable changes in the incidence of occupational diseases include a decline in chronic poisonings, elimination of lead poisoning, a considerable reduction in the incidence of hepatitis, a marked reduction of the voice organ pathologies as well as improvement of the detection of asbestos-related diseases through implementation of the program of medical examinations of former workers of asbestos processing plants.

The disadvantages include an underestimated number of cases of asthma, cancer and pathologies of the musculoskeletal system, in comparison to data from other countries. 


\section{CONCLUSION}

The study indicates the need:

- to investigate the impact of systemic factors on the processes of occupational disease recognition;

- to analyze and verify the list of occupational diseases in terms of hazards and annoying factors occurring in today's work environment;

- to perform assessments of the occupational fraction, particularly regarding asthma, malignant neoplasms and pathologies of the musculoskeletal system. Such underestimation of these health problems leads to their marginalization and thus adversely affects their prevention.

\section{ACKNOWLEDGMENTS}

We would like to thank Mr. Wojciech Sobala for supervising the database system and Mrs. Danuta Drożdż for technical assistance in this work.

\section{REFERENCES}

1. Commission of the European Communities. Commission recommendation of 19/09/2003 concerning the European schedule of occupational diseases, Report No. C(2003) 3297. Brussels: Commission of the European Communities, 2003 [cited 2012 Sept 2]. Available from http://eur-lex.europa.eu/ LexUriServ/LexUriServ.do?uri=CELEX:32003H0670:EN: HTML.

2. Szeszenia-Dąbrowska N, Świątkowska B, Szubert Z, Wilczyńska U. Asbestos in Poland occupational health problems. Int J Occup Med Environ Health 2011;24(2):142-52.

3. International Labour Office. Guidelines for the Use of ILO International Classification Radiographs of Pneumoconioses. Geneva: ILO; 1980.

4. Consensus Report. International expert meeting on new advances in radiology and screening of asbestos-related diseases. Scand J Work Environ Health 2000;26:449-54.
5. Marek K. Principles of work capacity assessment in occupational respiratory diseases. Med Pr 2002;53(3):245-52 [in Polish].

6. Śliwińska-Kowalska M, Niebudek-Bogusz E, Fiszer M, LosSpychalska T, Kotyło P, Sznurowska-Przygocka B, et al. The Prevalence and risk factors for occupational voice disorders in teachers. Folia Phoniatr Logop 2006;58:85-101.

7. Sliwińska-Kowalska M, editor. Principles for opinioning on applicant's capacity to perform jobs associated with exposure to noise and excessive vocal effort and diagnosing and preventing of hearing and vocal organ diseases. Warszawa: Centrum Medyczne Kształcenia Podyplomowego; 2011. p. 168 [in Polish].

8. Wilczyńska U, Szeszenia-Dąbrowska N. Occupational diseases among health and social workers in Poland. Med Pr 2010;61(6):597-605 [in Polish].

9. Bilski B. Viral hepatitis as an occupational disease in Poland. Hepat Mon 2011;11(7):539-43.

10. Ayres JG, Boyd R, Cowie H, Hurley JF. Costs of occupational asthma in the UK. Thorax 2011;66(2):128-33.

11. Fingerhut M, Nelson DI, Driscoll T, Concha-Barrientos M, Steenland K, Punnett L, et al. The contribution of occupational risk to the global burden of disease: summary and next steps. Med Lav 2006;97(2):313-21.

12. Gautrin D, Newman-Taylor AJ, Nordman H, Malo JL. Controversies in epidemiology of occupational asthma. Eur Respir J 2003;22(3):551-9.

13. Nelson DI, Concha-Barrientos M, Driscoll T, Steenland K, Fingerhut M, Punnett L, et al. The global burden of selected occupational diseases and injury risks: Methodology and summary. Am J Ind Med 2005;48(6):400-18.

14. Jeebhay MF, Quirce S. Occupational asthma in the developing and industrialised world: A review. Int $\mathrm{J}$ Tuberc Dis 2007;11(2):122-33.

15. Karjalainen A, Kurppa K, Martikainen R, Klaukka T, Karjalainen J. Work is related to a substantial portion of adult-onset asthma incidence in the Finnish population. Am J Respir Crit Care Med 2001;164(4):565-8.

16. Karjalainen A, Niederlaender E. Occupational diseases in Europe in 2001. Statistics in focus - population and social 
conditions - 15/2004 [cited 2012 September 2]. Available from URL: http://epp.eurostat.ec.europa.eu/cache/ITY OFFPUB/KS-NK-04-015/EN/KS-NK-04-015-EN.PDF

17. Vandenplas O, Lantin AC, D’Alpaos V, Larbanois A, Hoet P, Bandeweerdt $\mathrm{M}$, et al. Time trends in occupational asthma in Belgium. Respir Med 2011;105(9):1364-72.

18. Brhel P. Occupational respiratory diseases in the Czech Republic. Ind Health 2003;41(2):121-3.

19. Karjalainen A, Kurppa K, Virtanen S, Keskinen H, Nordman H. Incidence of occupational asthma by occupation and industry in Finland. Am J Ind Med 2000;37(5):451-8.

20. Wilczyńska U, Szeszenia-Dąbrowska N. Occupational bronchial asthma in Poland in 2003-2007. Przegl Lek 2008;65 Suppl 2:1-4 [in Polish].

21. Lombardo LJ, Balmes JR. Occupational asthma: Review. Environ Health Perspect 2000;108 Suppl 4:697-704.

22. Doll R, Peto R. The causes of cancer quantitative estimates of avoidable risk of cancer in United States today. J Natl Cancer Inst 1981;66:1191-308.

23. Rushton L, Bagga S, Bevan R, Brown TP, Cherrie JW, Holmes P, et al. Occupation and cancer in Britain. Br J Cancer 2010;102(9):1428-37.

24. Boffetta P, Autier P, Boniol M, Boyle P, Hill C, Aurengo A, et al. An estimate of cancers attributable to occupational exposures in France. J Occup Environ Med 2010;52(4): 399-406.

25. Dreyer L, Andersen A, Pukkala E. Avoidable cancers in Nordic countries. APMIS 1977;Suppl 76:68-79.

26. Vineis P, Simonato L. Proportion of lung and bladder cancer in males resulting from occupation: A systematic approach. Arch Environ Health 1991;46(1):6-15.

27. Rushton L, Bagga S, Bevan R, Brown TP, Cherrie JW, Holmes P, et al. The burden of occupational cancer in Great Britain [cited 2012 Sept 2]. Health and Safety Executive 2010, RR800. Available from http://www.hse.gov.uk/ research/rrpdf/rr800.pdf.
28. Fabianova E, Szeszenia-Dąbrowska N, Kjaerheim K, Boffetta P. Occupational cancer in Central European countries. Environ Health Perspect 1999;107(2):279-82.

29. Bruske-Hohlfeld I. Occupational cancer in Germany. Environ Health Perspect 1999;107 Suppl 2:253-58.

30. Scarselli A, Scano P, Mariccio A, Iavicoli S. Occupational cancer in Italy: Evaluating the extent of compensated cases in period 1994-2006. Am J Ind Med 2009;52(11):859-67.

31. Andersson E, Toren K. Pleural mesotheliomas are underreported as occupational cancer in Sweden. Am J Ind Med 1995;27:577-80.

32. Skov T, Mikkelsen S, Svane O, Lynge E. Reporting of occupational cancer in Denmark. Scand J Work Environ Health 1990;16:401-5.

33. Brugere J, Thebaud-Mony A, Pezerat H, Cassou B. Occupational cancers: Notification, compensation and prevention. Bull Cancer 1994;81(1):14-21 [in French].

34. Boffetta P. Occupational cancer epidemiology. G Ital Med Lav Ergon 2011;33(3):290-3.

35. Rushton L, Hutchings S, Brown T. The burden of cancer at work estimation as the first step to prevention. Occup Environ Med 2008;65(12):789-800.

36. Da Costa BR, Vieira ER. Risk factors for work-related musculoskeletal disorders: A systematic review of recent longitudinal studies. Am J Ind Med 2010;53(3):285-323.

37. Muggleton JM, Allen R, Chappell PH. Hand and arm injuries associated with repetitive manual work in industry: A review of disorders, risk factors and preventive measures. Ergonomics 1999;42(5):714-39.

38. Waersted M, Hanvold TN, Veiersted KB. Computer work and musculoskeletal disorders of the neck and upper extremity: A systematic review. BMC Musculoskelet Disord 2010;11:79.

39. Szeszenia-Dąbrowska N, Wilczyńska U. Occupational diseases in the period of socioeconomic transition in Poland. Int J Occup Med Environ Health 2006;2:99-106.

40. Central Statistical Office. Employment in National Economy in 2009. Warszawa: GUS; 2010. p. 170 [in Polish].

This work is available in Open Access model and licensed under a Creative Commons Attribution-NonCommercial 3.0 Poland License - http://creativecommons.org/ licenses/by-nc/3.0/pl/deed.en. 